PORTIONS OF THIS REPORT ARE ILLEGIBLE. II has been reproduced from the best available

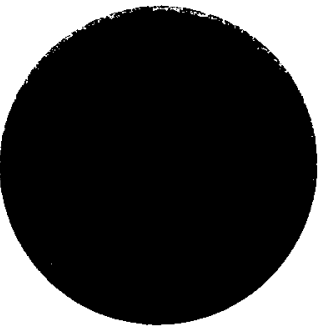
copy to permit the broadest possible availability.

$$
\text { DOE/ID/ } 2478 \text { - TQ }
$$

\title{
GEO-HEAT
}

CENTER

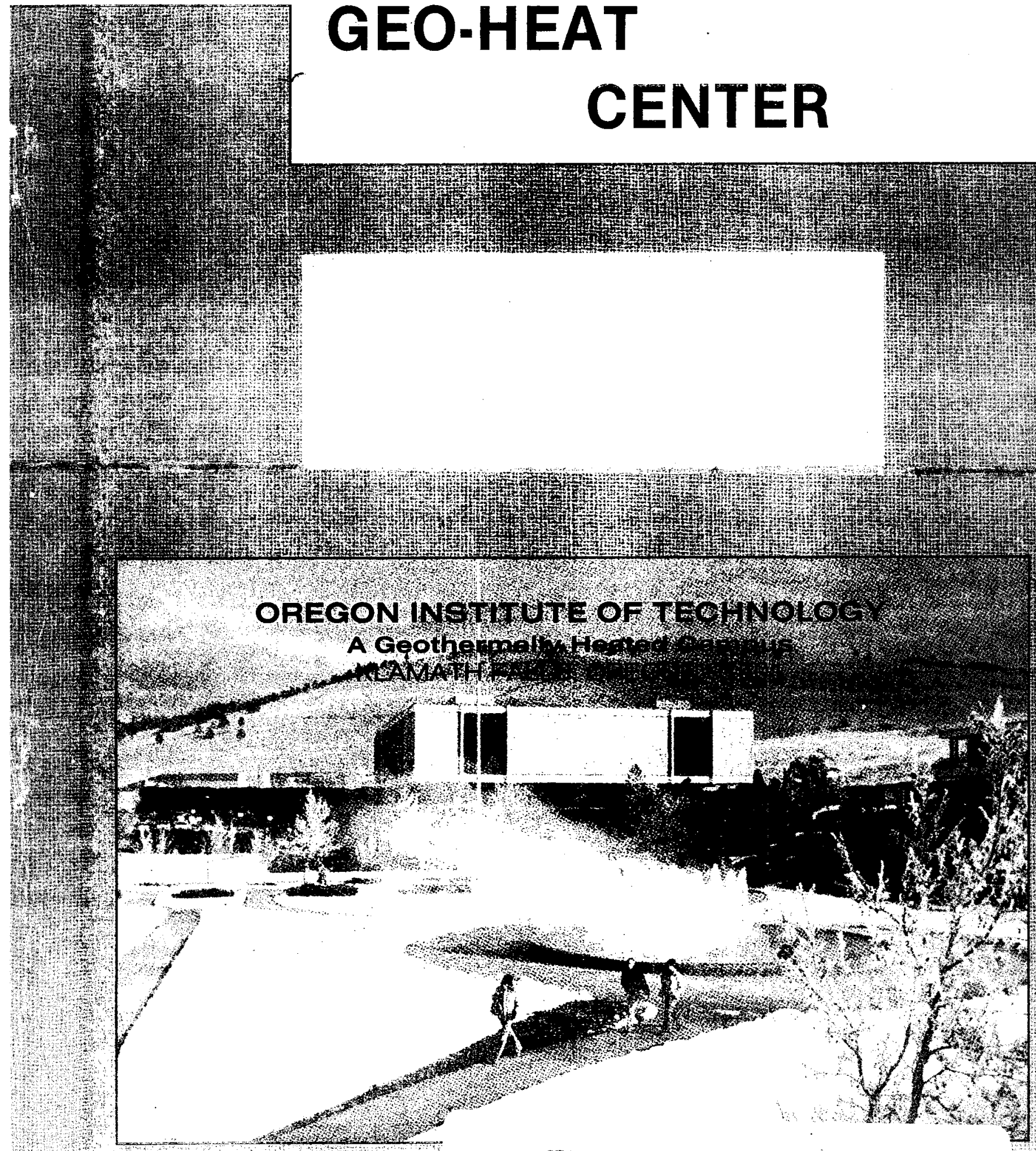

CAMABHTION OF THIS DOCHMENT IS BWEMTIED 
DOE/ID/ $12478--\mathrm{r} 2$

DE84 016297

\section{GEOTHERMAL HEATING SYSTEM \\ for the \\ Children's Museum of Utah}

JuTy 1984

\footnotetext{
By:

THORBJORN KARLSSON, Research Associate Geo-Heat Center Oregon Institute of Technology $\mathrm{Klamath}$ Falls, Oregon 97601
} 


\section{DISCLAIMER}

This report was prepared as an account of work sponsored by an agency of the United States Government. Neither the United States Government nor any agency Thereof, nor any of their employees, makes any warranty, express or implied, or assumes any legal liability or responsibility for the accuracy, completeness, or usefulness of any information, apparatus, product, or process disclosed, or represents that its use would not infringe privately owned rights. Reference herein to any specific commercial product, process, or service by trade name, trademark, manufacturer, or otherwise does not necessarily constitute or imply its endorsement, recommendation, or favoring by the United States Government or any agency thereof. The views and opinions of authors expressed herein do not necessarily state or reflect those of the United States Government or any agency thereof. 


\section{DISCLAIMER}

Portions of this document may be illegible in electronic image products. Images are produced from the best available original document. 


\section{DISCLIIMER}

This report was prepared as an account of work sponsored by the United States Government. Neither the United States nor the United States Department of Energy, nor any of their employees, nor any of their contractors, subcontractors, or their employees, makes any warranty, expressed or implied, or assumes any legal responsibility for the accuracy, completeness or usefulness of any information, apparatus, product or process disclosed, or represents that its use would not infringe privately-owned rights. 
TABLE OF CONTENTS

Page

Introduction

Summary of Conclusions

The Wasatch Hot Spring Geothermal Resource

3

Heating Requirements in Children's Museum Building

11

Present and Planned Space Heating

14

Geothermal Space Heating Possibilities

17

Capital and Operating Costs of Geothermal System

19

Economic Analysis

19

References 


\section{GEOTHERMAL HEATING SYSTEM \\ FOR THE \\ CHILDREN'S MUSEUM OF UTAH \\ Salt Lake City, Utah}

\section{INTRODUCTION}

The Children's Museum of Utah was opened in October 1983 in an old building located at. $840 \mathrm{~N} .300 \mathrm{~W}$ in Salt Lake City. The building was constructed during the early part of this century as a resort, housing two swimming pools, an 01 ympic size one and a smaller one, and a few guest rooms. This use of the building was discontinued in the fifties and the building was abandoned. It was becoming run down and dilapidated when taken over by the Museum. As of today, the Museum is using only some 4,500 square feet out of a total of about 35,000 square feet of floor area.

The plans for future utilization of the building are not at all firm. Work is underway to extend the museum into an approximately 3,500 square foot area on the first floor in the south end of the building. The big pool area, over 10,000 square feet, will be converted into a restaurant and the small pool area, approximately 2,000 square feet, is being planned as an auditorium. Both pool areas extend up through the building, but other parts of the building are two stories. The northwest end of the second level will provide for office space for the museum whereas the remaining second level space will be used for additional exhibits. A basement in the area underneath the south end of the building will probably be used as a work shop for the museum once it has expanded throughout the whole building (Lance Robson, Exhibits Comittee, personal communication).

The building is located in the southerly part of the so called Warm Springs Fault geothermal area which is a strip approximately three miles long by 4,000 feet wide that parallels the western edge of the Salt Lake salient to the northwest of the Utah State Capitol Building (Murphy and Gwynn, 1979). The observed occurrences of warm water along the Warm Springs Fault are bound on the north by Beck Hot Springs and on the south by Wasatch Hot Spring (Figure 1). The 


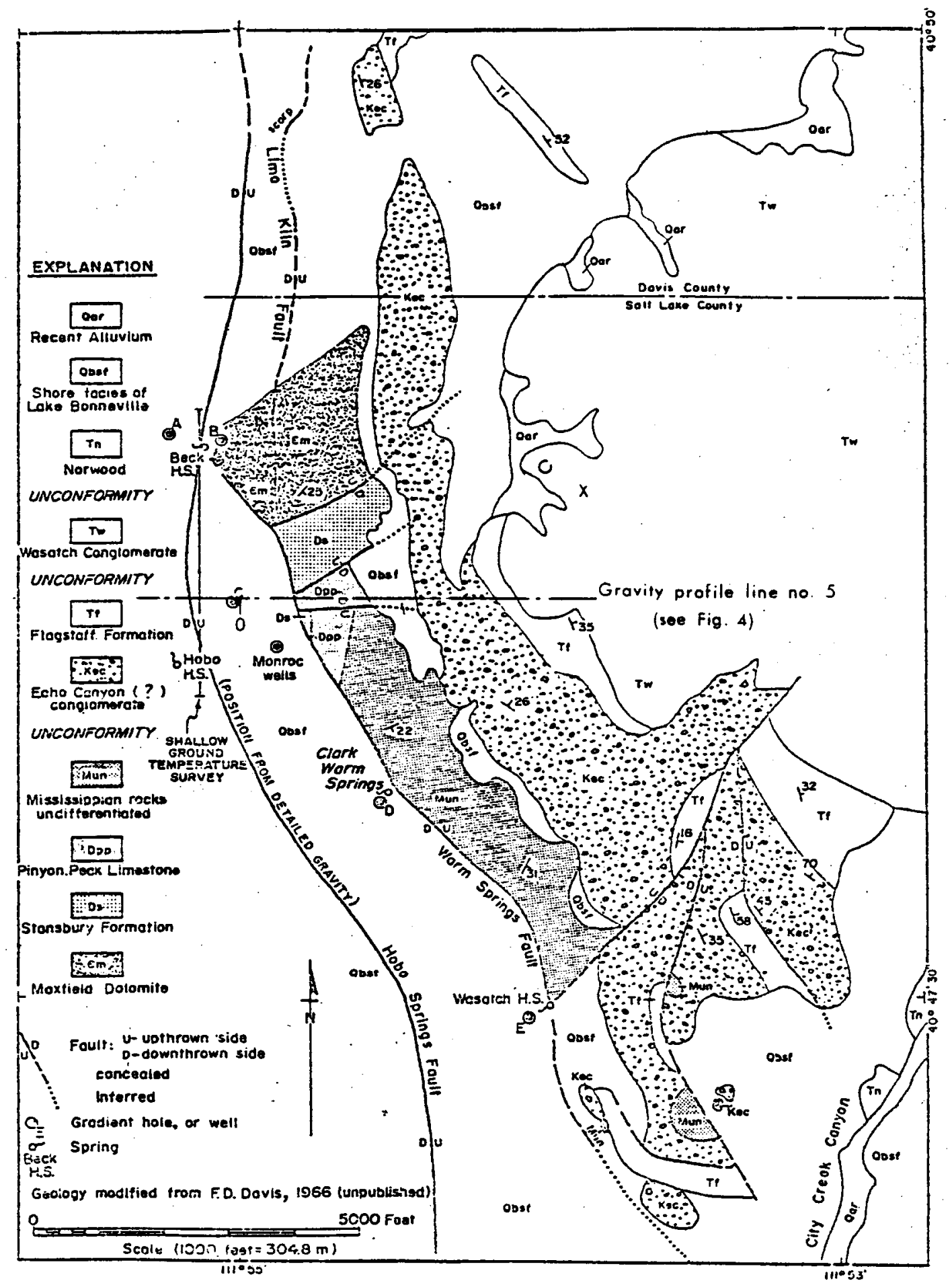

FIGURE 1

Geologic Map of Warm Springs Fault Area,

Salt Lake and Davis Counties, Utah

(from Murphy and Gwynn, 1979) 
Wasatch Hot Spring supplied water to the swimming pools when they were in operation.

This report presents the results of a study to determine the engineering and economic feasibility of using the Wasatch Hot Spring resource for space heating of the Children's Library building.

\section{SUMMARY OF CONCLUSIONS}

The Wasatch Hot Spring with a reported flow of about $63 \mathrm{gpm}(240 \mathrm{l} / \mathrm{min}$ ) at an average temperature of $104^{\circ} \mathrm{F}$ is not capable of furnishing the needed heat for the Children's Museum building. The underground paths along which the thermal waters flow to their outlets at the Warm Springs Fault are not presently known. It is possible if the thermal water ascends from the deep layers of the earth along the Warm Springs Fault that increased geothermal flow at a higher temperature can be produced by drilling into the fault.

Assuming that sufficient geothermal fluid quantity is produced by drilling in the area, an analysis is made of a geothermal heating system for the building based on different fluid temperatures. It is assumed that the present and planned heating systems be left intact with the gas fired boilers taking over during cold periods when the geothermal system fails to provide sufficient heat. Economic analysis shows that the geothermal system is very attractive, even for the lowest geothermal fluid temperature considered $\left(110^{\circ} \mathrm{F}\right)$.

In view of these results, it is recommended that an exploratory well be drilled in the vicinity of the Wasatch Hot Spring in order to establish the underground flow path. Only then can it be determined whether or not a geothermal heating system for the Children's Museum of Utah is feasible.

\section{THE WASATCH HOT SPRING GEOTHERMAL RESOURCE}

The Wasatch Hot Spring is approximately one mile northwest of the Utah 
State Capitol Building between Victory Road and Beck Street. At one time the spring supplied water to the Wasatch swimming pools located in the building which now houses the Children's Museum of Utah. Over the years, when the swimming pools were in operation, a series of six tunnels were driven northeastward into cemented alluvium and tufa deposits in attempts to increase the spring flow. The tunneling usually increased the flow temporarily, but the discharge eventually decreased with time. The spring discharge also varies with seasonal and climactic variations. Temperatures ranging from $38^{\circ} \mathrm{C}$ to $42^{\circ} \mathrm{C}$ $\left(100.4^{\circ}\right.$ to $107.6^{\circ} \mathrm{F}$ ) have been reported (Murphy and Gwynn, 1979)(Cole, 1982, 1983), and the average discharge is $240 \mathrm{l} /$ minute $(63.4 \mathrm{gpm}$, Cole, 1983).

The Wasatch Hot Spring constitutes the southernmost observed occurence of warm water along the Warm Springs Fault (Figure 1). The Warm Springs Fault geothermal system has been the subject of several studies (e.g. Murphy and Gwynn, 1979; Cole, 1982, 1983). Most of the information on the Wasatch Hot Spring presented below is drawn from these sources.

The total dissolved solids contents (TDS) of Warm Springs Fault thermal waters range from 6,000 to $14,000 \mathrm{mg} / \mathrm{l}$. In general, water with the highest TDS value is found at the northern end of the system. Beck Hot Springs, Hobo Hot Springs, and the Monroc water wells (Figure 1) all produce water in the TDS content range from 12,800 to $13,900 \mathrm{mg} / \mathrm{l}$. At the southern extend of the known warm water occurrences, Wasatch Hot Spring has a TDS value of approximately $6,000 \mathrm{mg} / \ell$. Water from Clark Warm Spring is between these two extremes with a TDS content of approximately $9,700 \mathrm{mg} / \ell$ (Murphy and Gwynn, 1979).

Systematic chemical variations through time are characteristic of hot springs issuing from the Warm Springs Fault. The observed chemical contents will therefore depend on the time of year as indicated by Figure 2 which shows chemical data in $\mathrm{mg} / \ell$ and temperature in ${ }^{\circ} \mathrm{C}$ sampled at the Wasatch Hot Spring for a period of more than a year and plotted against time in weeks. The figure indicates cyclical changes in water chemistry where chemical enrichment is observed during the summer months and depletions occur during fall and early winter months. These chemical variations are accompanied by corresponding 


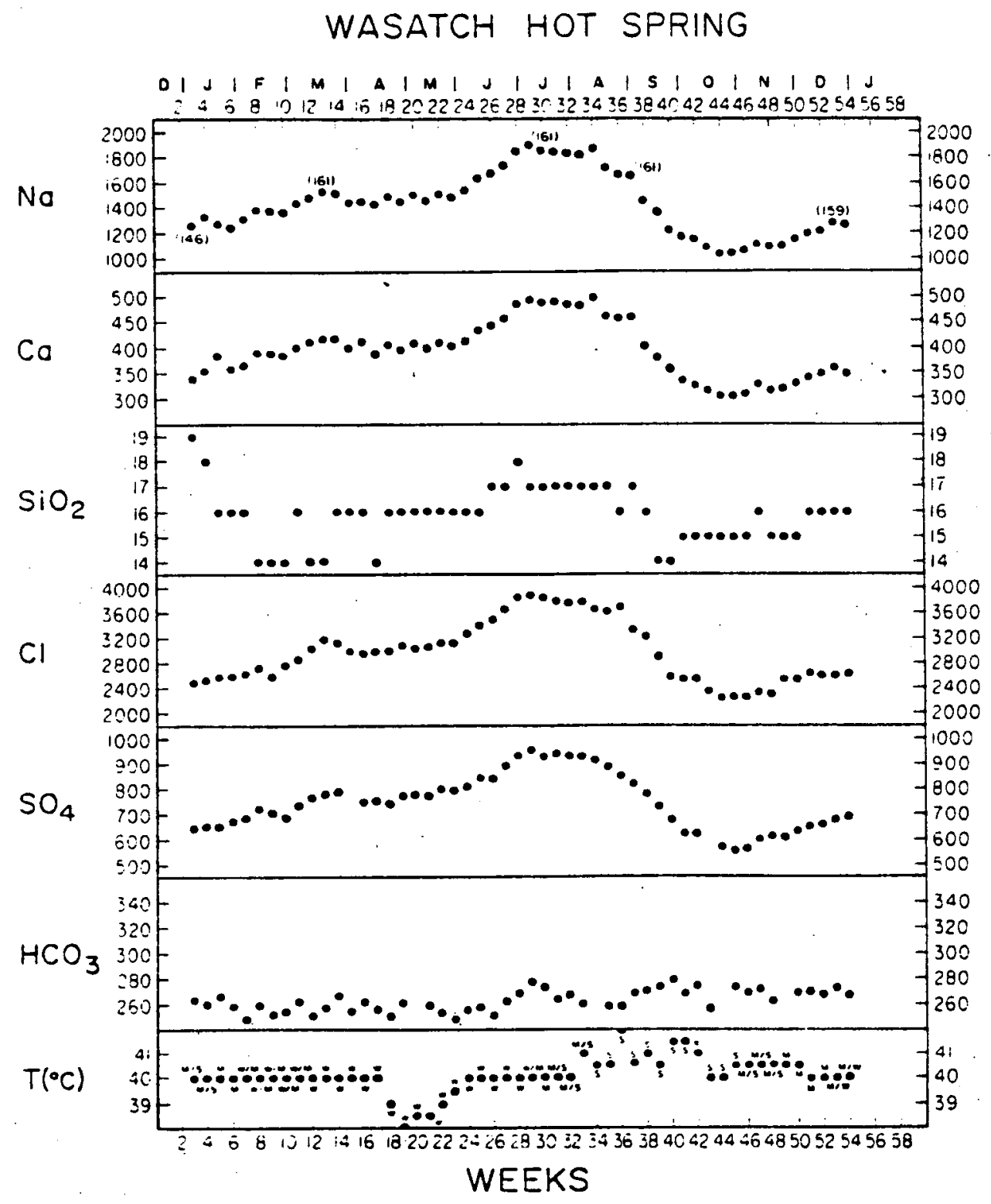

FIGURE 2

Selected Chemical Compositions and Temperatures for Wasatch Hot Springs Plotted Against Time in Weeks. The Numbers in ( ) are the $\mathrm{Na} / \mathrm{K} / \mathrm{Ca}$ Geothermometer Temperatures for Those Weeks. $W=$ Weak Flow Rate; $W / M=$ Weak to Moderate Flow; $M / S=$ Moderate to Strong Flow Rate; $S$ = Strong Flow Rate. From Cole (1983) 
changes in temperature and flow rates. For example, during the summer months at times of maximum flow, the hot spring exhibits its highest surface temperatures.

The correlation of maximum and minimum surface temperatures with chemical enrichments and depletions, respectively, strongly suggests that mixing is the major process controlling the cyclic nature of the chemistry and temperature. The high concentrations of elements occur during periods when influx of nonthermal groundwater is the lowest. Significant declines in the concentrations of $\mathrm{Na}, \mathrm{Ca}, \mathrm{SiO}_{2}, \mathrm{Cl}$ and $\mathrm{SO}_{4}$ coincide with declines in surface temperatures. A nonthermal end member temperature of $22^{\circ} \mathrm{C}$ to $28^{\circ} \mathrm{C}\left(71.6^{\circ}\right.$ to $\left.82.4^{\circ} \mathrm{F}\right)$ is required, assuming that it has a TDS of $500 \mathrm{mg} / \mathrm{l}$ or less, which is typical of valley groundwaters adjacent to the Warm Springs Fault zone. If this cool water is derived initially from mountain snow packs, the duration of time from recharge to discharge is estimated to be four to six months. This estimate is arrived at by assuming that major recharge occurs during the spring thaw (April-May) and by noting that the pattern of major dilution in chemistry occurs in September and October (Cole, 1982, 1983).

In the fall of 1978 the Utah Geological and Mineral Survey (UGMS) contracted with Peterson Brothers Drilling Company of Salt Lake City, Utah, to dril1 13 temperature gradient holes in northern Utah. Five of these holes were located along the Warm Springs Fault (marked A, B, C, D, E in Figure 1). The holes were logged by UGMS, samples were taken every 5 to 10 feet, and temperatures were measured in January-February, 1979 (Murphy and Gwynn, 1979).

Figure 3 shows the temperature profile in hole $E$ which is located about 75 meters (246 feet) west of the Wasatch Hot Spring outlet. The hole was drilled through a series of sands and gravels containing varying percentages of clay. The generally elevated temperatures measured below five meters are the result of lateral flow of warm water through the sands and gravels from the spring system located to the east (Murphy and Gwynn, 1979). 


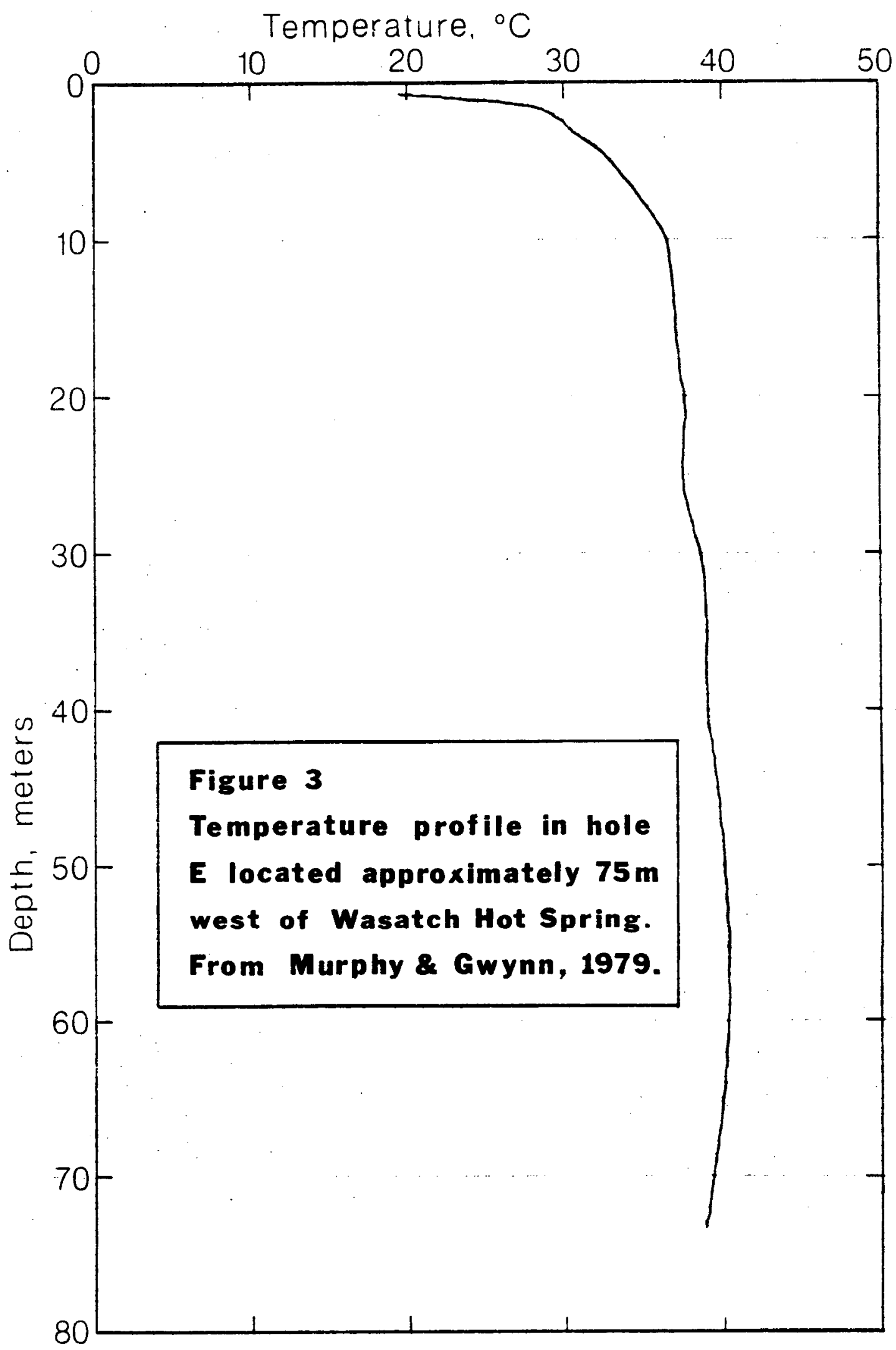


A detailed gravity survey of the Warm Springs Fault geothermal area was made for the UGMS in February 1979. The survey consisted of 12 east-west gravity lines along which stations were spaced at 500 to 1,000 feet intervals. One of the 12 gravity profiles, profile number 5, has been modeled using a three dimensional gravity modeling program. The observed gravity profile 5, the modeled gravity profile and a simple bedrock-alluvium model are presented in Figure 4. The actual location of profile 5 is shown in Figure 1. The model consists of two faults on the eastern edge, a deep alluvium filled graben and a horst block on the western edge. The easternmost fault corresponds to the Warm Springs Fault, and the downthrown block is covered by several hundred feet of alluvium. Approximately 1,500 feet to the west a single and almost vertical fault having approximately 4,000 feet of relief defines the eastern edge of the deep graben. This fault corresponds to the Hobo Springs Fault in Figure 1. At the western edge of the graben a horst block rises to within approximately 1,500 feet of the surface (Murphy and Gwynn, 1979).

Some variations in the shapes of the gravity profiles appear in the gravity survey but the general model described above appears to be applicable all along the Warm Springs Fault. The width of and depth to the downthrown block of the fault increase to the south of line 5 (see Figure 1), but displacement across the Warm Springs Fault remains minor in comparison to the Hobo Springs Fault to the west.

On the basis of the above observations, Murphy and Gwynn (1979) reached the following conclusions about the hot water system in the Warm Springs Fault geothermal area.

1. The occurrence of warm water in the area appears to be controlled by two main Basin and Range structures: a) the Warm Springs Fault striking northwest and dipping 65 to $70^{\circ}$ to the southwest, and b) the Hobo Springs Fault striking subparallel to the Warm Springs Fault and dipping slightly to the southwest, close to $90^{\circ}$. 


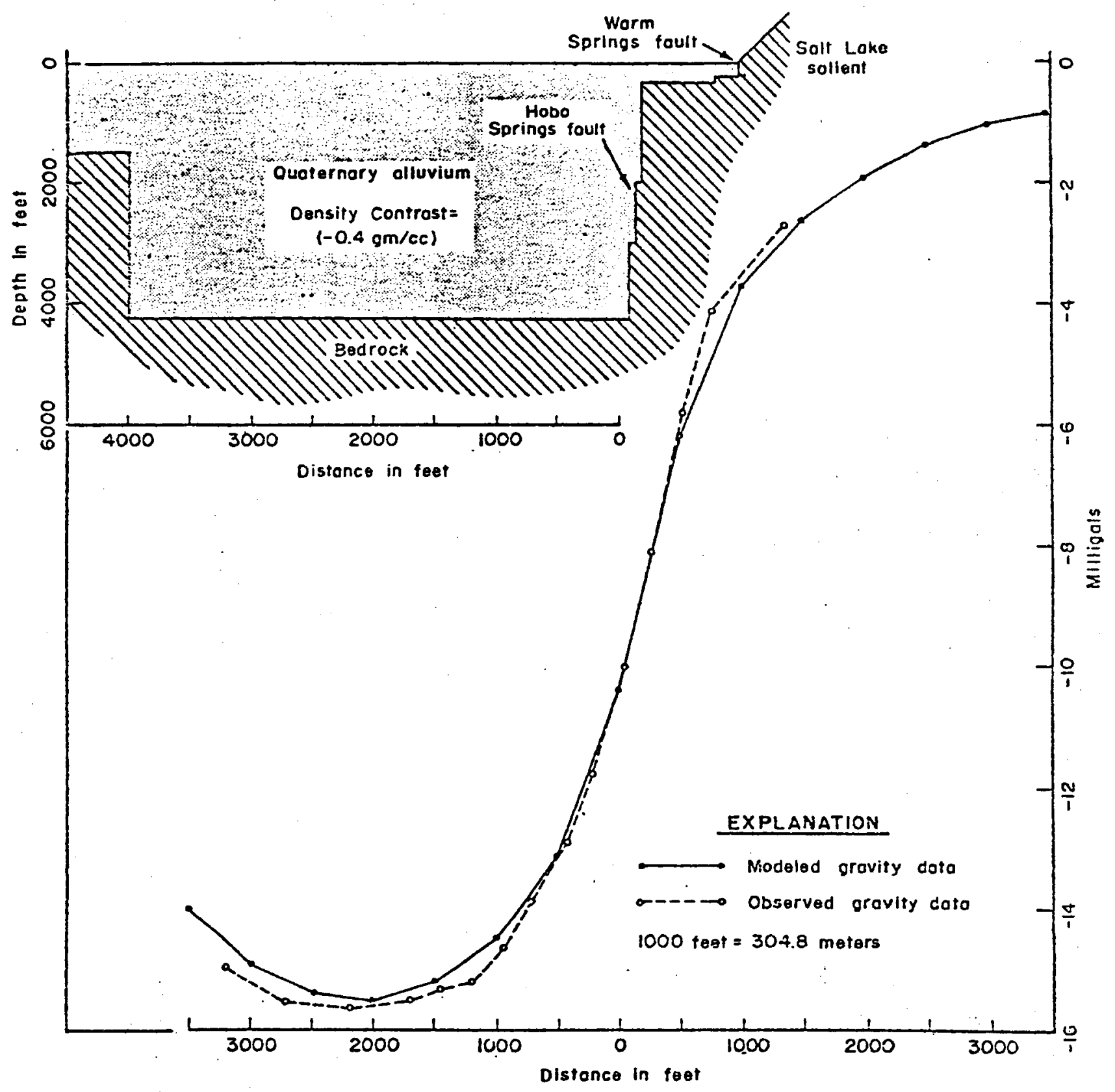

FIGURE 4

Model and Gravity Profiles for Line 5, Warm Springs Fault Detailed Gravity Survey, Salt Lake County, Utah (from

Murphy and Gwynn, 1979) 
2. There is little doubt that recharge to the Warm Springs Fault thermal spring system originates in the Wasatch Mountains east of the Salt Lake salient. Steeply dipping aquifers and numerous faults could easily transport the water to the required depth. The path by which the water actualiy descends to depth, however, is not presently known.

3. The Warm Springs Fault geothermal system is a convective system in which water is circulated to depth and heated by the relatively high geothermal gradient of the Basin and Range province. After being heated by the elevated temperatures at depth, the water rises quickly along faults to the surface where it is discharged into near surface aquifers, and to the surface as springs.

Cole (1983) found by geothermometer calculations utilizing either quartz (no steam loss), chalcedony, or $\mathrm{Mg}$-corrected $\mathrm{Na} / \mathrm{K} / \mathrm{Ca}$ methods (Fournier, 1981) that most thermal springs in Utah have aquifer temperatures occurring in the range from $25^{\circ}$ to $120^{\circ} \mathrm{C}\left(77^{\circ}\right.$ to $\left.248^{\circ} \mathrm{F}\right)$. This temperature range suggests that fluid circulation along the steeply dipping faults which control hot spring activity is restricted to depths of three to four kilometers $(9,800$ to 13,000 feet), assuming thermal gradients ranging from $32^{\circ}$ to $40^{\circ} \mathrm{C} / \mathrm{km}$.

The cyclic variation of the water chemistry in the Wasatch Hot Spring described by Cole (1983, see Figure 2) suggests mixing of cool groundwater with ascending thermal water as previously described. Where along the path of the flowing water this mixing takes place may be an important factor in deciding the usability of the thermal waters along the Warm Springs Fault. There are two different possibilities:

1. The thermal water which is circulated to depth and heated in the deep layers of the Basin and Range province flows laterally at depth and ascends along faults such as the Warm Springs Fault. As it nears the surface, it is mixed with the cool water which has traveled laterally from the mountains through the surface layers. This appears to be the model described in the papers by Murphy and Gwynn (1979) and Cole (1983). 
2. The thermal water rises under the Range where it is mixed with the cool surface water. From there it flows laterally to its outlets along faults such as the Warm Springs Fault. Some investigators have expressed the opinion that this possibility is no less likely than the first (R. Klauk, UGMS, personal communication).

It is clear that the first of the above models offers a good chance of producing considerably warmer water than is now flowing from the Wasatch Hot spring. This can be done by drilling a well down to the Warm Springs Fault below the downthrown block and casing off the overiying water bearing alluvium layer. A proposed design of such a well is shown in Figure 5. Figure 6 (from Gill, 1980) shows the location of the Children's Museum relative to the Warm Springs Fault. A well designed to cut the fault as shown in Figure 5 could probably be located within the city owned property line as shown in Figure 6 .

If the thermal waters follow the path described by the second model, no temperature increase of the water is produced by drilling in the area. It is therefore of importance for the future utilization of the Warm Springs Fault geothermal field to establish the actual flow model for the area.

\section{HEATING REQUIREMENTS IN CHILDREN'S MUSEUM BUILDING}

Estimates of the heating requirements of the Children's Museum building are based on the following information received from Joseph Linton, Wayne Bingham, Architects, Salt Lake City, who prepared the plans for refurbishing the building for the Museum.

1. Ail exterior walls are poured concrete, 12 inches thick and uninsulated.

2. All floors between main and second levels and between basement and main levels are reinforced concrete with rigid insulation.

3. Roofs are reinforced concrete and assumed to be uninsulated. 


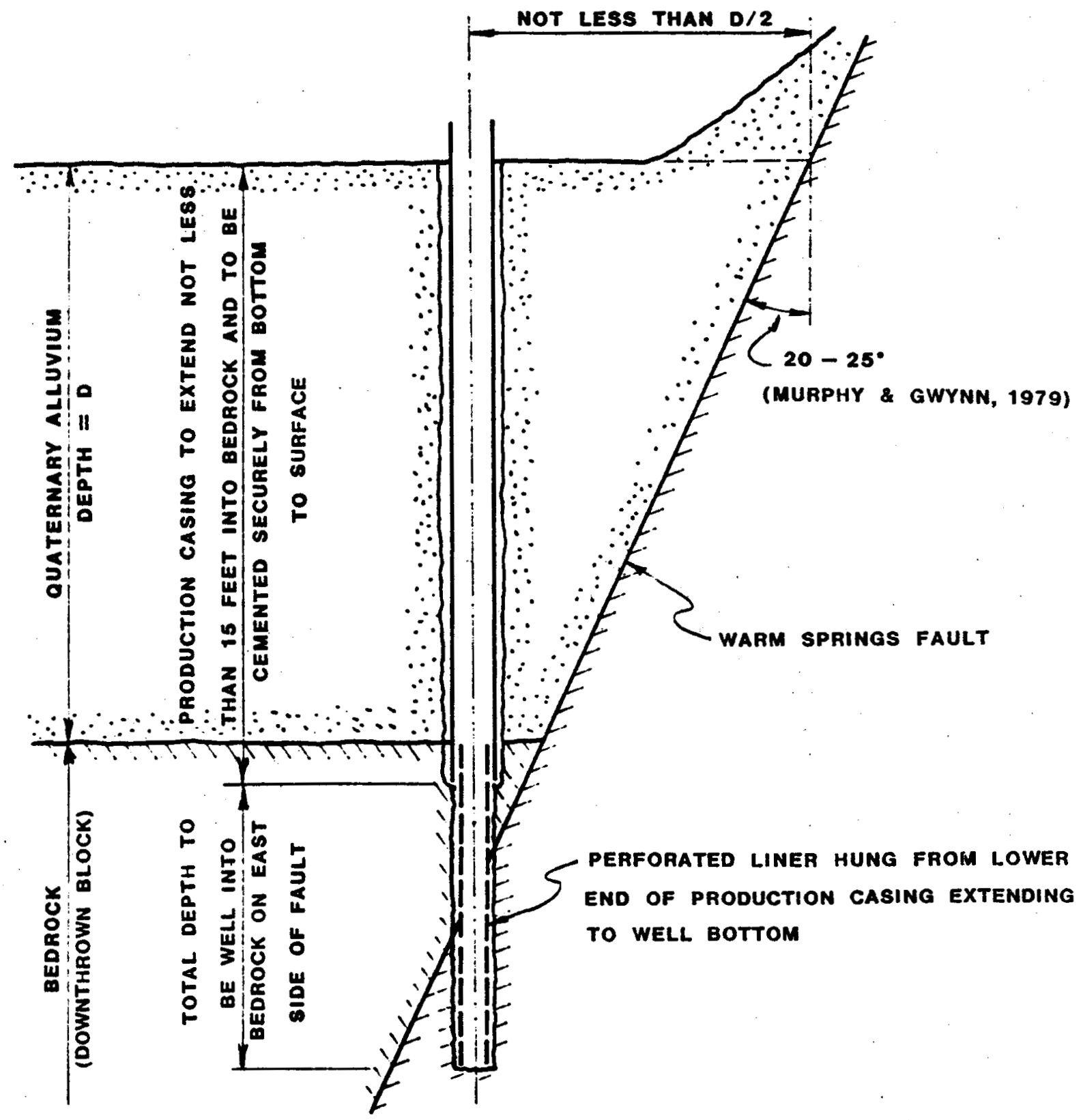

FIGURE 5

Proposed Positioning and Design of Well to be Drilled Near Children's Museum of Utah.

Section Across Warm Springs Fault Looking North-Northwest 


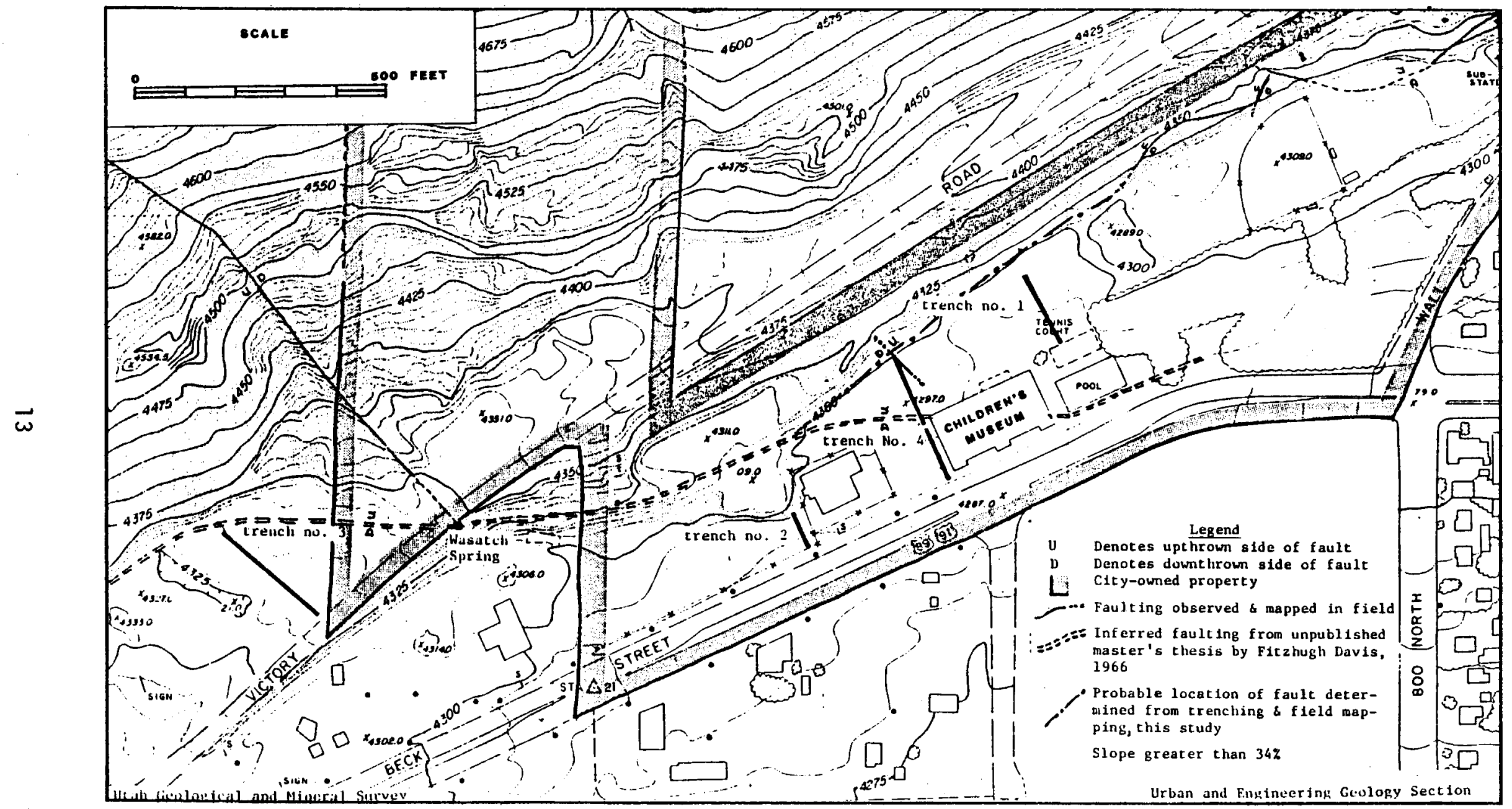

FIGURE 6

Location of Children's Museum of Utah in Relation to the Warm Springs Fault and Wasatch Hot Spring (from Gill, 1980) 
4. Windows are single pane, wood frame.

Outside design air temperature was chosen at $3^{\circ} \mathrm{F}(99 \%$ value, ASHRAE Handbook, 1977 Fundamentals, p. 23.14). It is assumed that the building will be taken into use in eight phases in order as listed below:

Phase 1: Main entrance with vestibule, lobby, reception, office, and rooms $\# 1$ and 2 as marked on Sheet no. A4, dated July 1982, prepared by Joseph Linton, Wayne Bingham, Architects. This is the part of the building already in use. Phase 2: South end of building, main level. This is the area now being refurbished and will be opened in a few weeks.

Phase 3: Large pool area (restaurant).

Phase 4: Small pool area (auditorium).

Phase 5: Space in northwest corner of building on main level.

Phase 6: Northern end of second level, including space above main entrance.

Phase 7: Remaining part of second level.

Phase 8: Basement under southern end of building.

In calculating the heat loss for each phase it was assumed that phases not yet in use would remain unheated. The results of the heat loss calculations are presented in Table I.

The table shows a rather high heat loss per square foot of floor area. This is not unexpected since the building is uninsulated and because of the very great ceiling height in the two pool areas.

\section{PRESENT AND PLANNED SPACE HEATING}

New heating systems have been designed and installed in those parts of the Children's Museum building already in use and in the part which is now being 
TABLE I

Heating Requirements of

Children's Museum Building by Phases

\begin{tabular}{|c|c|c|c|c|c|c|c|c|c|}
\hline \multicolumn{2}{|c|}{ Phases in Use } & 1 & $1-2$ & $1-3$ & $1-4$ & $1-5$ & $1-6$ & $1-7$ & A11 \\
\hline \multicolumn{2}{|c|}{ Floor Area Heated, $\mathrm{ft}^{2}$} & 4,450 & 7,923 & 18,239 & 20,520 & 22,107 & 26,496 & 31,696 & 35,224 \\
\hline \multicolumn{2}{|c|}{ Vol ume Heated, $\mathrm{ft}^{3}$} & 44,722 & 79,452 & 378,098 & 429,888 & 445,758 & 480,873 & 522,471 & 554,223 \\
\hline \multirow{8}{*}{$\begin{array}{l}\text { Heat } \\
\text { Losses } \\
\text { by Phase } \\
\text { Btu/hr }\end{array}$} & 1 & 274,008 & 260,142 & 244,068 & 244,068 & 241,197 & 192,932 & 165,724 & 165,724 \\
\hline & 2 & - & 282,500 & 275,715 & 275,715 & 275,715 & 275,715 & 213,826 & 151,937 \\
\hline & 3 & - & - & 950,719 & 934,689 & 934,689 & 927,797 & 918,123 & 918,123 \\
\hline & 4 & - & - & - & 316,703 & 313,478 & 309,612 & 309,612 & 309,612 \\
\hline & 5 & - & - & - & - & 69,511 & 54,323 & 54,323 & 54,323 \\
\hline & 6 & - & - & - & - & - & 258,067 & 255,703 & 255,703 \\
\hline & 7 & - & - & - & - & - & - & 315,584 & 315,584 \\
\hline & 8 & - & - & - & - & - & - & $=$ & 62,245 \\
\hline \multicolumn{2}{|c|}{ Total Heat Loss, Btu/hr } & 274,008 & 542,642 & $1,470,502$ & $1,771,175$ & $1,834,590$ & $2,018,446$ & $2,232,895$ & $2,233,251$ \\
\hline \multicolumn{2}{|c|}{ Total Heat Loss, Btu/hr $\times \mathrm{ft}^{2}$} & 61.6 & 68.5 & 80.6 & 86.3 & 83.0 & 76.2 & 70.4 & 63.4 \\
\hline \multicolumn{2}{|c|}{ Total Heat Loss, Btu/hr $\times \mathrm{ft}^{3}$} & 6.13 & 6.83 & 3.89 & 4.12 & 4.12 & 4.20 & 4.27 & 4.03 \\
\hline
\end{tabular}


refurbished, i.e. in phases 1 and 2. These systems have been designed by Dale R. Wilde Co./Engineers in Salt Lake City. The short description of the systems which follows is based on information furnished by the designers (Ray Wilde, engineer, personal communication).

Phase 1 heating system. The heating system in phase 1 consists of finned tube hot water radiators. The equipment is designed to operate at an entering water temperature of $200^{\circ} \mathrm{F}$ and a leaving water temperature of $160^{\circ} \mathrm{F}$. Entering air temperature to the finned tube units is assumed to be $65^{\circ} \mathrm{F}$. Most of the finned tube radiators are of the two tier type with a rated output of 2,110 Btu/hr $\times$ If at design conditions.

Boiler room equipment consists of a gas fired Ajax water heating boiler rated at $675,000 \mathrm{Btu} / \mathrm{hr}$ input, 540,000 Btu/hr output, and a hot water circulating pump, Bell \& Gossett, $36.8 \mathrm{gpm}$ at $26 \mathrm{ft}$ head, driven by an electric motor, $120 / 60 / 1,3 / 4 \mathrm{HP}, 1,750 \mathrm{rpm}$.

Phase 2 heating system. The installation of the phase 2 heating system is completed and this part will be taken into use in a few weeks. In this design the space above phase 2 (part of phase 7) and the basement below (phase 8) are grouped together with the phase 2 heating system. The system is of the same type as the phase 1 heating system, i.e. finned tube radiators and the design temperatures are the same, entering water at $200^{\circ} \mathrm{F}$, leaving water at $160^{\circ} \mathrm{F}$, entering air at $65^{\circ} \mathrm{F}$.

Boiler room equipment consists of a gas fired Ajax water heating boiler, rated at $750,000 \mathrm{Btu} / \mathrm{hr}$ input, $600,000 \mathrm{Btu} / \mathrm{hr}$ output, and two hot water circulating pumps, Bel1 \& Gossett, $15 \mathrm{gpm}$ each at $45 \mathrm{ft}$ head, driven by electric motors, $120 / 60 / 1,3 / 4 \mathrm{HP}, 1,750 \mathrm{rpm}$.

Remaining space. In order to make an economic evaluation of the heating cost of the building, it is necessary to make some assumptions about the heating 
systems to be installed in the remaining space. These have not yet been designed but according to the designing engineers the plan is to install the same type of hot water system wherever feasible in the remaining space as already is operating in phases 1 and 2 . This means that all parts of the building except phases 3 and 4, the two pool areas, will have the same heating system. Due to the very great ceiling height and large heating requirements of the pool areas, the hot water finned tube radiators are not sufficient and will have to be supplemented by a forced air heating system.

It will be assumed that finned tube radiators supplying about 530,000 Btu/ $\mathrm{hr}$ can be installed in the pool areas leaving about $700,000 \mathrm{Btu} / \mathrm{hr}$ to be supplied by the forced air heating system (see Table I). The total peak heat requirements of the building are then met as follows:

$$
\begin{array}{ll}
\text { With finned tube radiators } & 1.54 \times 10^{6} \mathrm{Btu} / \mathrm{hr} \\
\text { With forced air heating } & 0.70 \times 10^{6} \mathrm{Btu} / \mathrm{hr}
\end{array}
$$

The installed boiler output capacity today is $114 \times 10^{6} \mathrm{Btu} / \mathrm{hr}$. An additional $600,000 \mathrm{Btu} / \mathrm{hr}$ boiler will be sufficient for the finned tube radiator systems and about $800,000 \mathrm{Btu} / \mathrm{hr}$ should take care of the air heating system.

\section{GEOTHERMAL SPACE HEATING POSSIBILITIES}

It is clear that the Wasatch Hot Spring with a mean flow of $63 \mathrm{gpm}(240 \mathrm{l} /$ min.) at a temperature of about $104^{\circ} \mathrm{F}\left(40^{\circ} \mathrm{C}\right)$ will not in any way be sufficient for space heating of the Children's Museum building. If geothermal is to be in the picture at all, some means must be found to obtain more geothermal water at a higher temperature. Two options come to mind in this connection.

1. Build a pipeline to transmit hot water from the Beck Hot Spring to the Children's Museum building. The Beck Spring has a discharge of about 230 gpm at $133^{\circ} \mathrm{F}$ (Cole, 1983). 
2. Drill a well in the neighborhood of the Wasatch Hot Spring intersecting the Warm Springs Fault below the downthrown block of the fault. By blocking off the inflow of groundwater it may be possible to catch warmer water ascending along the fault (see Figure 3 ).

The first of these options is technically feasible but the cost is obviously prohibitive. The pipeline alone of the size and type needed (6" insulated and buried fiber reinforced plastic pipe) will cost over 10 times more than a drilled geothermal production well.

The second option is technically feasible if the path of the geothermal fluid is from the deep layers of the earth, where the fluid receives its heat, up through the fault. As discussed previously, scientists are not at all certain about the path of the geothermal fluid flow to the Warm Springs Fault.

The analysis which follows is based on the second option. A geothermal production well drilled to a total depth of 800 feet is assumed to be capable of producing the required flow of water by pumping. The temperature of the water, however, is unknown and will be left as a variable quantity in the analys is.

The analysis includes a reinjection well to dispose of the geothermal fluid after it is used. This well will be shallower and narrower than the production wel1.

In order to keep retrofitting costs to a minimum, the heating systems which already have been installed in the building will be left unchanged. The heating systems for the remaining parts of the building will be the same as discussed in the last section. This way the retrofitting of the building to geothermal heating is very simple, requiring only the installation of heat exchangers in the mechanical room for removing the required heat from the geothermal fluid.

With the hot water finned tube radiators designed for an entering water temperature of $200^{\circ} \mathrm{F}$ it is clear that the geothermal fluid will not supply all the 
needed heating energy unless its temperature is we 11 above $200^{\circ} \mathrm{F}$. For lower temperatures it will, therefore, be necessary to maintain the three finned tube system boilers. These will then take over when the outside temperature drops below a minimum value, which depends on the geothermal fluid temperature. It is, however, assumed that the geothermal system will be capable of handling the forced air heating system without the aid of a boiler. A schematic diagram showing this system is presented in Figure 7 .

\section{CAPITAL AND OPERATING COSTS OF GEOTHERMAL SYSTEM}

Estimated capital and operating costs of the geothermal system are shown in Table II. As discussed in the last section, the temperature of the geothermal fluid is an unknown quantity so the estimates are made for several temperature values. A heat exchanger approach (difference between entering geothermal fluid temperature and leaving water temperature) of 5 to $6^{\circ} \mathrm{F}$ is assumed.

The capital cost items are independent of the fluid temperature except the plate heat exchanger cost. It increases with increased capacity (measured in Btu/hr). The heat exchanger, however, does not constitute a major cost item so that there is not a great difference in total capital cost between the highest and lowest fluid temperatures.

The maintenance cost of the geothermal system is independent of fluid temperature. The energy cost, on the other hand, is strongly influenced by the geothermal fluid temperature. The electricity is mainly that used for pumping the geothermal fluid from the production well through the heat exchanger. The fuel cost for the conventional operation of the heating system is reduced as the fluid temperature increases and the geothermal share of the heating of the building is increased.

\section{ECONOMIC ANALYSIS}

In order to make an economic comparison between the geothermal heating system 


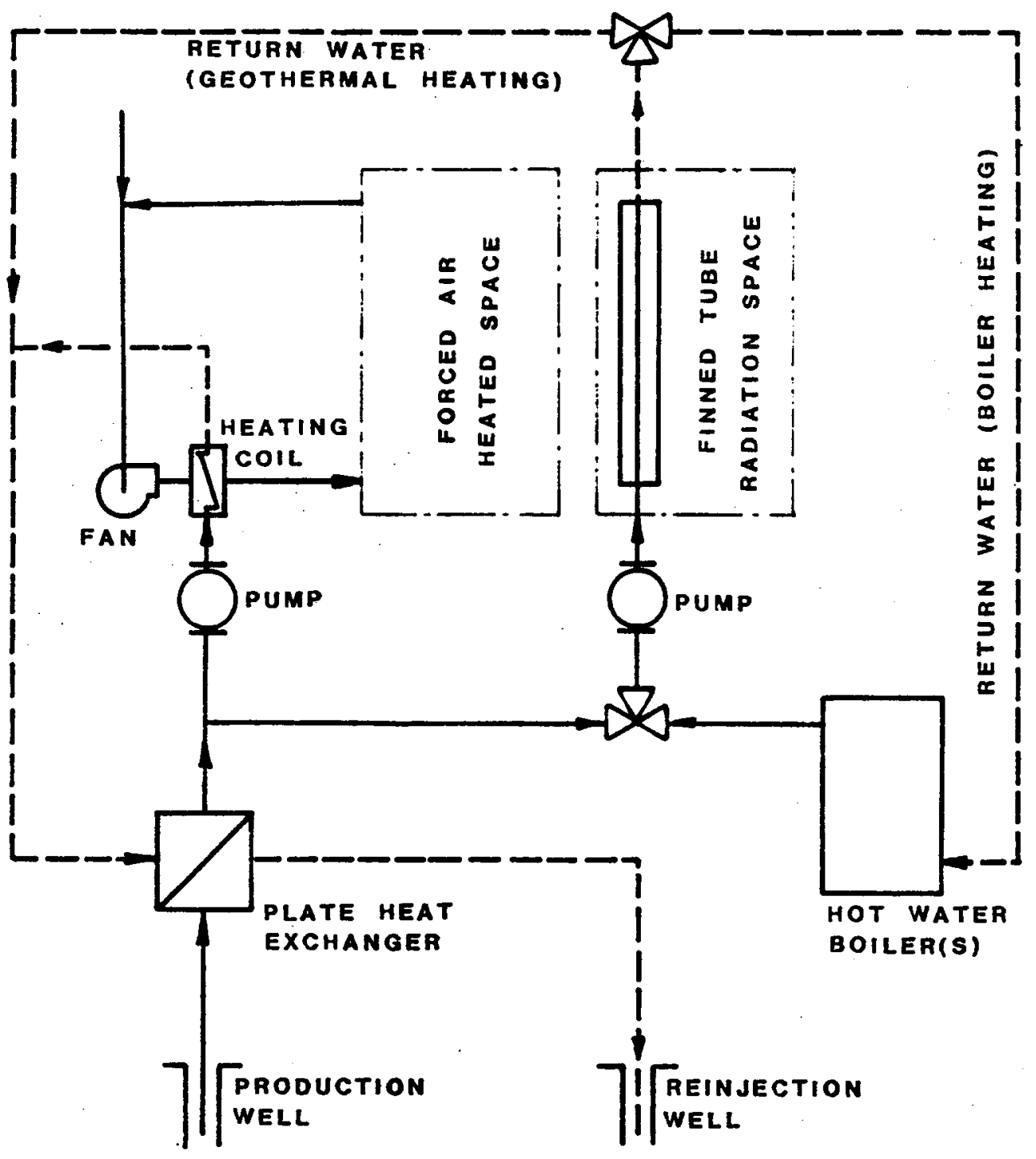

FIGURE 7

Schematic Flow Diagram of Proposed Hookup for Geothermal Heating of Children's Museum of Utah 


\section{TABLE II}

Capital and Operating Cost Estimates for Geothermal Heating System for Children's Museum of Utah

\begin{tabular}{|l|r|r|r|r|r|}
\hline Geothermal fluid temp., ${ }^{\circ} \mathrm{F}$ & 110 & 133 & 157 & 181 & 206 \\
Average heating water temp., ${ }^{\circ} \mathrm{F} *$ & 100 & 120 & 140 & 160 & 180 \\
Low outside air temp. W. geoth., ${ }^{\circ} \mathrm{F}$ & 57 & 45 & 32 & 18 & 3 \\
\hline
\end{tabular}

A. Capital Costs:

\begin{tabular}{|l|r|r|r|r|r|}
\hline Production wel1, 800' & 26,000 & 26,000 & 26,000 & 26,000 & 26,000 \\
Injection wel1, 400' & 10,000 & 10,000 & 10,000 & 10,000 & 10,000 \\
Downhole pumps \& drive & 32,000 & 32,000 & 32,000 & 32,000 & 32,000 \\
Wellihead building & 3,000 & 3,000 & 3,000 & 3,000 & 3,000 \\
Plate heat exchangers & 3,500 & 4,400 & 5,500 & 6,600 & 7,800 \\
Misc. piping, mechanical \& electrical & 25,000 & 25,000 & 25,000 & 25,000 & 25,000 \\
Engineering, 10\% & 10,000 & 10,100 & 10,200 & 10,300 & 10,400 \\
Subtotal & 109,500 & 110,500 & 111,700 & 112,900 & 114,200 \\
Contingency & 11,000 & 11,100 & 11,200 & 11,300 & 11,400 \\
TOTAL CAPITAL COST & 120,500 & 121,600 & 122,900 & 124,200 & 125,600 \\
\hline
\end{tabular}

B. Operating Costs:

\begin{tabular}{|l|r|r|r|r|r|}
\hline Maintenance & 2,500 & 2,500 & 2,500 & 2,500 & 2,500 \\
Energy cost: Electricity & 4,100 & 2,500 & 3,100 & 3,000 & 2,500 \\
Natural gas & 27,000 & 20,600 & 9,400 & 1,700 & 0 \\
\cline { 2 - 7 } TOTAL OPERATING COST & 33,600 & 25,600 & 15,000 & 7,200 & 5,000 \\
\hline
\end{tabular}

*At geothermal peak load. 
and the conventional system the annual savings with the geothermal system must be evaluated. As discussed previously it is assumed that the complete conventional system for the finned tube radiators be left intact since the geothermal system fails when the outside air temperature drops below a given value. On the other hand, the geothermal system is assumed to be capable of furnishing sufficient heat to the forced air heating system without the assistance of a peak load boiler. For the conventional system the forced air heating boiler must therefore be added and its cost taken into account in the economic comparison of the two systems.

The cost of a hot water boiler of the size needed for the forced air system installed and including a burner, expansion tank, and other accessories, is about $\$ 10,000$ (Means Mechanical Cost Data 1984). This cost is subtracted from the geothermal system capital cost for net payback evaluation. Maintenance cost of other parts of the conventional system are assumed to be the same with or without the geothermal system. The annual savings at present are then estimated as shown in Table III.

In order to arrive at cost figures over the 20 years assumed $1 \mathrm{ife}$ of the proposed geothermal heating system some assumptions must be made of rates of inflation and price escalations of operating cost items. For this analysis the forecast figures recently published by the California Energy Commission (CEC, March 1984) are used. These are as follows:

\begin{tabular}{lccc} 
Year & General Inflation & Natural Gas & Electricity \\
\cline { 2 - 4 } 1984 & 1.0000 & 1.0000 & 1.0000 \\
1985 & 1.0895 & 1.0857 & 1.1761 \\
1986 & 1.1535 & 1.1434 & 1.2221 \\
1987 & 1.2212 & 1.2745 & 1.2444 \\
$1988-2004$ & $6.5 \%$ per year & $\begin{array}{c}10.23 \% \text { per year } \\
\text { (average) }\end{array}$ & $\begin{array}{c}\text { 7.03\% per year } \\
\text { (average) }\end{array}$
\end{tabular}


TABLE III

Estimated Annual. Savings with

Geothermal Heating of the Children's Museum of Utah

\begin{tabular}{|l|l|l|l|l|l|}
\hline Geothermal fluid temp., ${ }^{\circ} \mathrm{F}$ & 110 & 133 & 157 & 181 & 206 \\
Ave. heating water temp., ${ }^{\circ} \mathrm{F}$ & 100 & 120 & 140 & 160 & 180 \\
\hline
\end{tabular}

Conventional heating:

\begin{tabular}{|l|r|r|r|r|r|}
\hline Electricity, 5300 kWh & 445 & 445 & 445 & 445 & 445 \\
Natural gas, 82,000 therms & 43,050 & 43,050 & 43,050 & 43,050 & 43,050 \\
$\quad$ Total annual cost & 43,495 & 43,495 & 43,495 & 43,495 & 43,495 \\
\hline
\end{tabular}

$\tilde{\omega}$

Geothermal heating:

\begin{tabular}{|l|r|r|r|r|r|}
\hline Maintenance & 2,500 & 2,500 & 2,500 & 2,500 & 2,500 \\
Electricity & 4,100 & 2,500 & 3,100 & 3,000 & 2,500 \\
Natural gas & 27,000 & 20,700 & 9,400 & 1,700 & 0 \\
Total annual cost & 33,600 & 25,600 & 15,000 & 7,200 & 5,000 \\
\hline
\end{tabular}

\begin{tabular}{|l|l|l|l|l|l|}
\hline Annual savings (present) & 9,895 & 17,895 & 28,495 & 36,295 & 38,495 \\
\hline
\end{tabular}


Maintenance cost of the geothermal system follows the general inflation rate.

The projected heating costs and savings with geothermal heating of the Children's Museum building over the 20 year period are shown in Table IV for the water temperature values considered. The total savings with the proposed geothermal system are shown in the last four columns of the table. It is seen that even at the lowest geothermal temperature, $110^{\circ} \mathrm{F}$, the project appears to be economically feasible with simple payback obtained in less than six years. Discounted payback at $12 \%$ is obtained in a 1 ittle over 9 years. It must be considered, however, that this temperature, $110^{\circ} \mathrm{F}$, is at the lower limit of what is technically feasible with the hot water radiator system in the building. Higher temperatures are preferred and the table shows that the payback period is rapidly reduced as the temperature is increased making the project very attractive indeed.

It should be borne in mind that the foregoing analysis is based on the assumption that sufficient amount of geothermal fluid (about $120 \mathrm{gpm}$ ) can be produced from a well drilled into the Warm Springs Fault. As discussed in the section on the Wasatch Hot Spring resource, the path along which the thermal water flows to its outlet is not known at present. It is not at all certain whether drilling in the area will result in added flow or higher temperature of the geothermal fluid. In view of the results of this study, it is recommended that an exploratory well be drilled in the vicinity of the Wasatch Hot Spring in order to establish the underground thermal water flow path. Only then can it be decided whether or not a geothermal heating system for the Children's Museum of Utah is feasible.

\section{REFERENCES}

1. ASHRAE Handbook - 1976 Systems. Third Printing 1979. American Society of Heating, Refrigerating and Air Conditioning Engineers, Inc., New York, NY 10017. 
TABLE IV

Heating Costs and Savings with

Geothermal Heating at Children's Museum of Utah

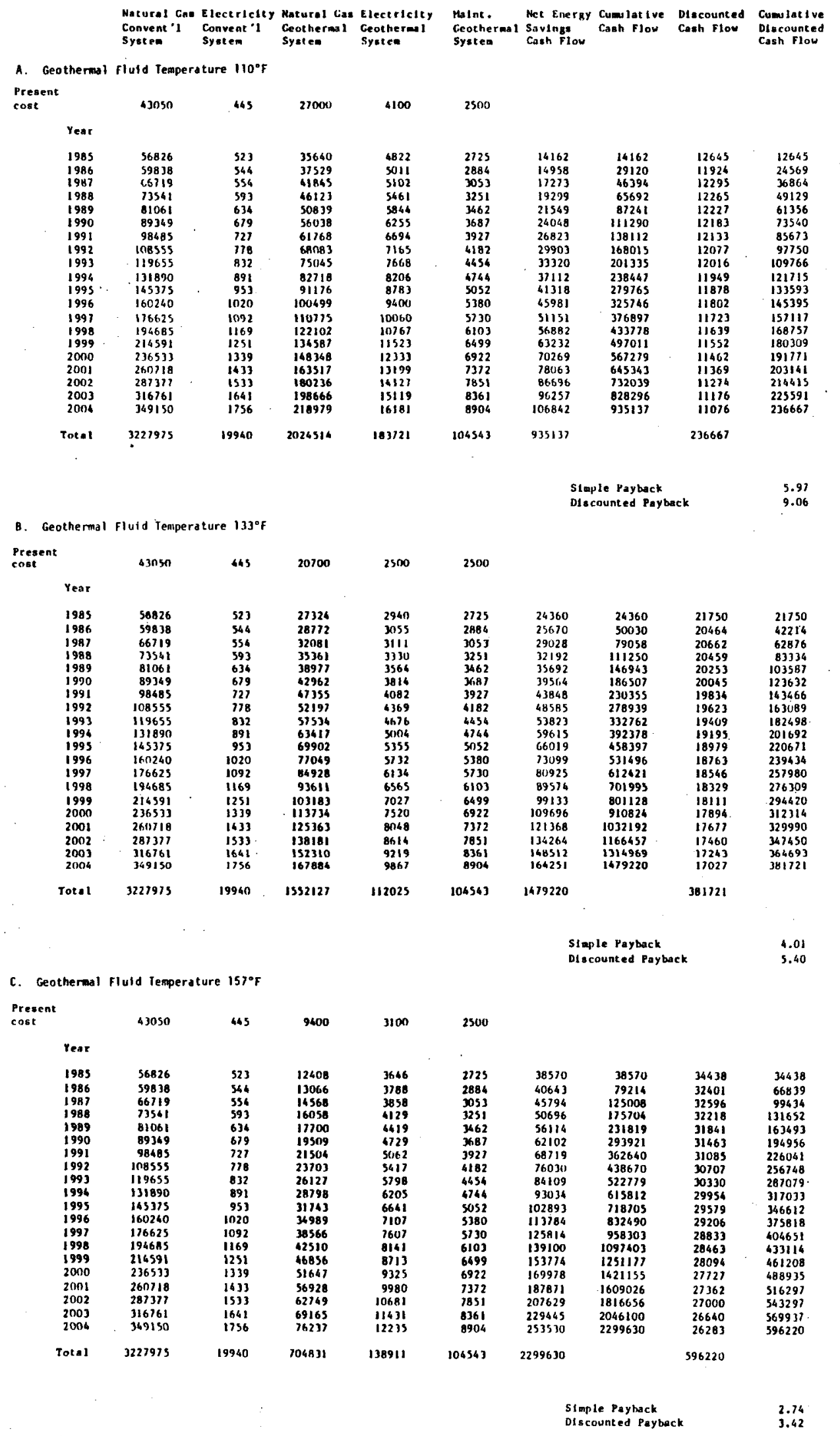


TABLE IV cont'd.

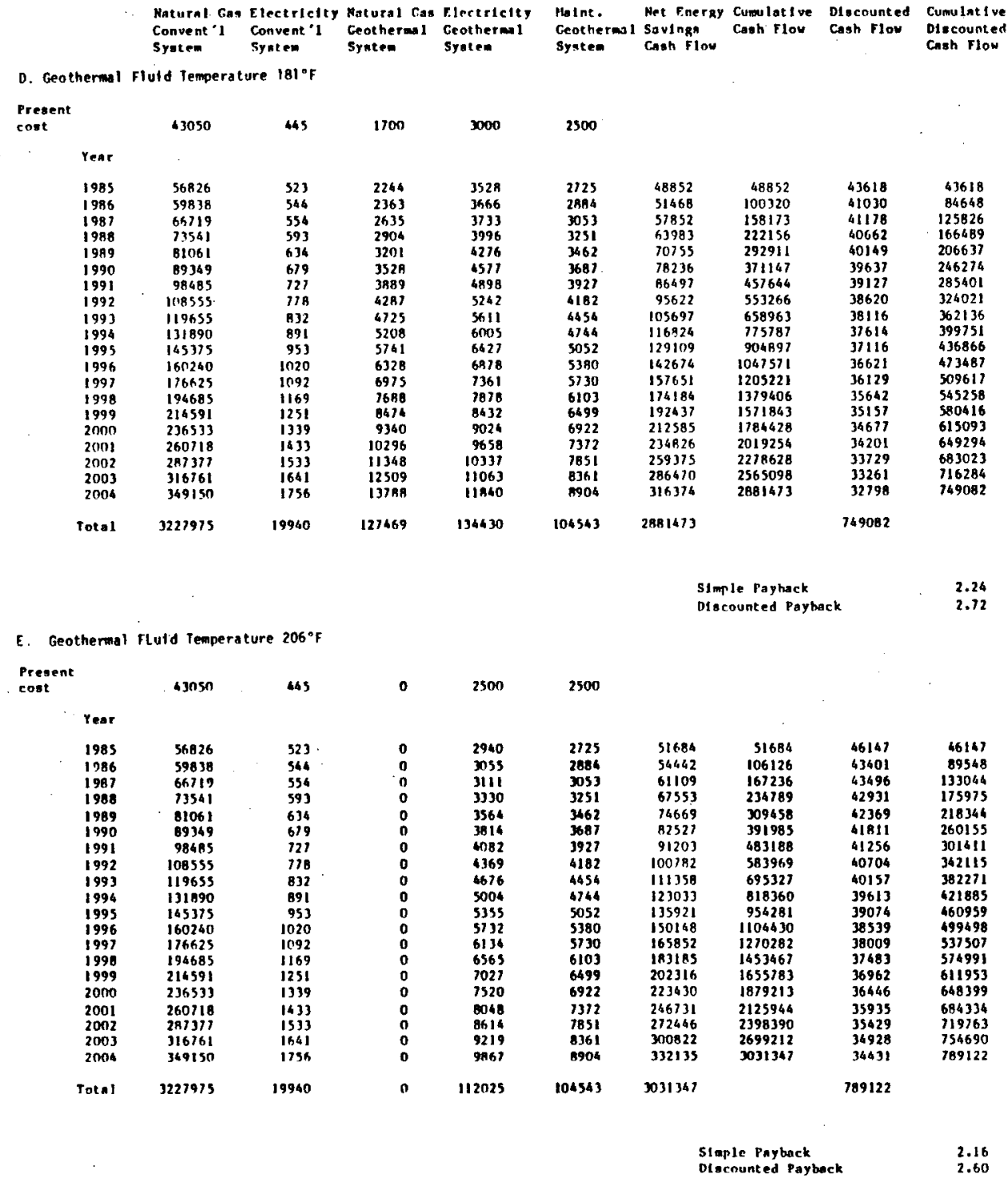


2. ASHRAE Handbook - 1977 Fundamentals. Second Printing 1978. American Society of Heating, Refrigerating and Air Conditioning Engineers, Inc., New York, NY 10017.

3. California Energy Commission, 1984a: Preliminary Energy Commission Staff Price Forecast for California Utilities. Prepared by the Systems Assessment Office Staff, March 1984.

4. California Energy Commission, 1984b: Summary of Preliminary Energy Commission Staff Natural Gas Price Forecasts by End Use Category 1984-2004. Prepared by the Fuels Assessment Office Staff, March 1984.

5. Cole, D.R., 1983: Chemical and Isotopic Investigation of Warm Springs Associated with Normal Faults in Utah. Journal of Volcanology and Geothermal Research, 16, pp 65-98. Elsevier Science Publishers B.V., Amsterdam, The Netherlands.

6. Fournier, R.0., 1981: Application of Water Geochemistry to Geothermal Exploration and Reservoir Engineering. Section 4, pp 109-143 in Geothermal Systems: Principles and Case Histories, edited by L. Rybach and L.J.P. Muffler. John Wiley \& Sons, Ltd.

7. Gill, H.E., 1980: Geotechnical Reconnaissance of the Wasatch Hot Springs Building Site. Investigation Report No. 158, Utah Geological and Mineral Survey.

8. Mossman, M.J. (editor-in-chief), 1983: Means Mechanical Cost Data 1984. Robert Snow Means Company, Inc., Kingston, MA 02364, 1983.

9. Murphy, P., and Gwynn, J.W., 1979: Geothermal Investigation of the Warm Springs Fault Geothermal System, Salt Lake County, Utah. Investigation Report No. 140, Utah Geological and Mineral Survey. 